\title{
Identification of clusters of asthma
}

\section{control: A preliminary analysis of the Inspirers studies}

\section{Identificar clusters de controlo da asma: Uma análise preliminar dos estudos Inspirers}

Data de receção / Received in: 16/12/2019

Data de aceitação / Accepted for publication in: 20/01/2020

Rev Port Imunoalergologia 2020;28 (4):23I-240

Cristina Jácome', Rita Amaral',2, Rute Almeida', Ana Margarida Pereira ${ }^{3}$, Mariana Couto ${ }^{4}$, Luís Araújo ${ }^{3}$, Magna Alves-Correia $^{3}$, Mariana Pereira ${ }^{1,5}$, Manuel Ferreira-Magalhães ${ }^{1,6}$, Cláudia Chaves Loureiro, Maria Joana Catarata $^{7}$, Lília Maia Santos ${ }^{7}$, Sara Cabral ${ }^{7}$, João Pereira ${ }^{7}$, Bárbara Ramos ${ }^{7}$, Cristina Lopes ${ }^{8,9}$, Ana Mendes ${ }^{10}$, Anabela Lopes ${ }^{10}$, José Carlos Cidrais Rodrigues", Georgeta Oliveira", Ana Paula Aguiar"l, Ivete Afonso ", Joana

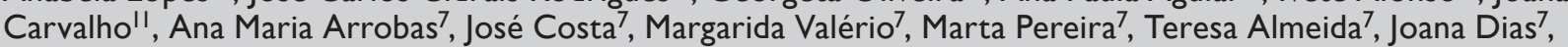
Ana Todo Bom ${ }^{12}$, João Azevedo ${ }^{13}$, Carmelita Ribeiro'2, Marta Alves ${ }^{12}$, Paula Leiria Pinto ${ }^{14}$, Nuno Neuparth ${ }^{14,15}$, Ana Castro Neves ${ }^{14}$, Ana Palhinha ${ }^{14}$, João Gaspar Marques ${ }^{14,15}$, Pedro Martins ${ }^{14,15}$, David Pina Trincão ${ }^{16}$, Filipa Todo Bom ${ }^{17}$, Maria Alvarenga Santos ${ }^{17}$, Joana Branco ${ }^{17}$, Alberto Costa ${ }^{18}$, Armandina Silva Neto ${ }^{18}$, Marta Santalha ${ }^{18}$, Carlos Lozoya ${ }^{19}$, Natacha Santos ${ }^{20}$, Diana Silva ${ }^{21}$, Maria João Vasconcelos ${ }^{21}$, Luís Taborda Barata ${ }^{22}$, Maria Fernanda Teixeira ${ }^{6}$, Diana Pinto ${ }^{6}$, Rodrigo Rodrigues Alves ${ }^{23}$, Ana Sofia Moreira ${ }^{23}$, Cláudia Sofia Pinto ${ }^{24}$, Pedro Morais Silva ${ }^{25}$, Carlos Alves ${ }^{26}$, Raquel Câmara ${ }^{26}$, Didina Coelho ${ }^{26}$, Diana Bordalo, ${ }^{1,27}$, Fernanda Carvalho ${ }^{27}$, Ricardo Fernandes ${ }^{28,29}$, Rosário Ferreira ${ }^{28}$, José Ferraz de Oliveira ${ }^{30}$, Fernando Menezes ${ }^{31}$, Ricardo Gomes ${ }^{31}$, Maria José Calix ${ }^{32}$, Ana Marques ${ }^{32}$, João Cardoso ${ }^{33}$, Madalena Emiliano ${ }^{33}$, Rita Gerardo ${ }^{33}$, Carlos Nunes ${ }^{34}$, José Alberto Ferreira ${ }^{35}$, Inês Lopes ${ }^{35}$, Adelaide Alves ${ }^{36}$, João Almeida Fonseca ${ }^{* 1,3,5,37}$, INSPIRERS group

I CINTESIS - Center for Health Technology and Services Research, Faculty of Medicine, University of Porto

${ }^{2}$ Dept. of Cardiovascular and Respiratory Sciences, Porto Health School, Polytechnic Institute of Porto

${ }^{3}$ Imunoalergologia, CUF Porto Instituto \& Hospital

${ }^{4}$ Imunoalergologia, José de Mello Saúde

${ }^{5}$ MEDIDA - Medicina, Educação, Investigação, Desenvolvimento e Avaliação, Porto

${ }^{6}$ Serviço de Pediatria, Centro Materno Infantil do Norte, Centro Hospitalar Universitário do Porto

${ }^{7}$ Serviço de Pneumologia, Centro Hospitalar e Universitário de Coimbra

${ }^{8}$ Unidade de Imunoalergologia, Hospital Pedro Hispano, Unidade Local de Saúde de Matosinhos

${ }^{9}$ Imunologia Básica e Clínica, Faculdade de Medicina, Universidade do Porto

${ }^{10}$ Serviço de Imunoalergologia, Hospital de Santa Maria, Centro Hospitalar Lisboa Norte

" Serviço de Pediatria, Hospital Pedro Hispano, Unidade Local de Saúde de Matosinhos

12 Serviço de Imunoalergologia, Centro Hospitalar e Universitário de Coimbra

${ }^{13}$ Imunoalergologia, Centro Hospitalar de Leiria

${ }^{14}$ Serviço de Imunoalergologia, Hospital de Dona Estefânia, Centro Hospitalar Universitário de Lisboa Central

${ }^{15}$ Pathophysiology, CHRC, Environmental Health research group, CEDOC, NOVA Medical School / Faculdade de Ciências Médicas, Lisboa 


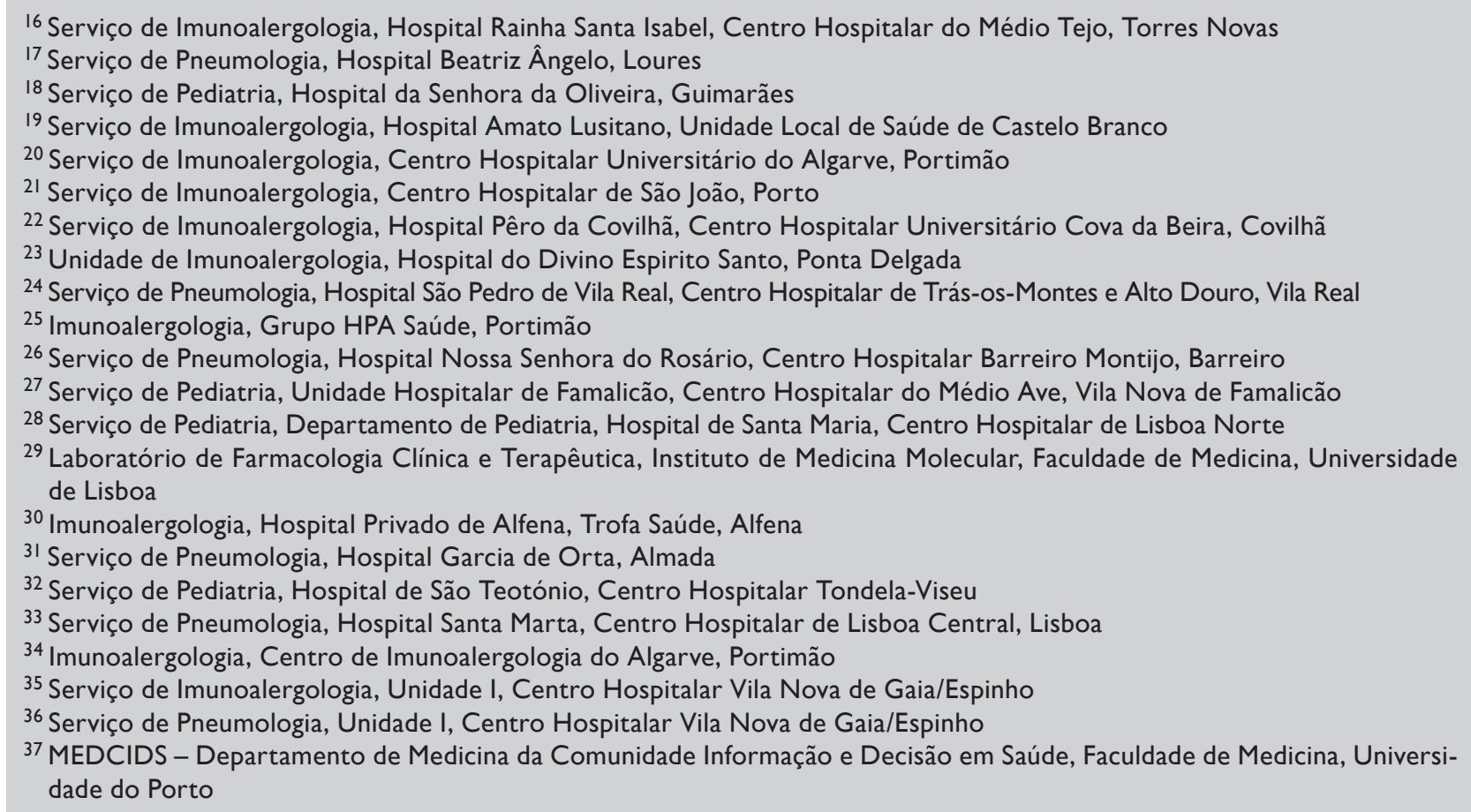

\section{ABSTRACT}

Aims: To identify distinct asthma control clusters based on Control of Allergic Rhinitis and Asthma Test (CARAT) and to compare patients' characteristics among these clusters. Methods: Adults and adolescents ( $\geq 13$ years) with persistent asthma were recruited at 29 Portuguese hospital outpatient clinics, in the context of two observational studies of the INSPIRERS project. Demographic and clinical characteristics, adherence to inhaled medication, beliefs about inhaled medication, anxiety and depression, quality of life, and asthma control (CARAT, $>24$ good control) were collected. Hierarchical cluster analysis was performed using CARAT total score (CARAT-T). Results: 410 patients (68\% adults), with a median (percentile 25-percentile 75) age of 28 (16-46) years, were analysed. Three clusters were identified [mean CARAT-T (min-max)]: cluster I [27(24-30)], cluster 2 [19(14-23)] and cluster 3 [10(2-13)]. Patients in cluster I (34\%) were characterised by better asthma control, better quality of life, higher inhaler adherence and use of a single inhaler. Patients in clusters 2 (50\%) and 3 (16\%) had uncontrolled asthma, lower inhaler adherence, more symptoms of anxiety and depression and more than half had at least one exacerbation in the previous year. Furthermore, patients in cluster 3 were predominantly female, had more unscheduled medical visits and more anxiety symptoms, perceived a higher necessity of their prescribed inhalers but also higher levels of concern about taking these inhalers. There were no differences in age, body mass index, lung function, smoking status, hospital admissions or specialist physician follow-up time among the three clusters. Conclusion: An unsupervised method based on CARAT$-T$, identified 3 clusters of patients with distinct, clinically meaningful characteristics. The cluster with better asthma control had a cut-off similar to the established in the validation study of CARAT and an additional cut-off seems to distinguish more severe disease. Further research is necessary to validate the asthma control clusters identified.

Keywords: Asthma, asthma control, classification, cluster analysis, control of allergic rhinitis and asthma test. 


\section{RESUMO}

Objetivos: Identificar clusters de controlo da asma baseados no Teste de Controlo da Asma e Rinite Alérgica (CARAT) e comparar as características dos doentes nos diferentes clusters. Métodos: Adultos e adolescentes ( $\geq 13$ anos) com asma persistente foram recrutados em 29 centros no contexto de 2 estudos observacionais do projeto INSPIRERS. Foram recolhidos dados relativos a características demográficas e clínicas, adesão ao inalador, crenças sobre a medicação, sintomas de ansiedade e depressão, qualidade de vida e controlo da asma (CARAT, >24 bom controlo). Foi efetuada uma análise hierárquica de clusters usando a pontuação total do CARAT (CARAT-T). Resultados: Foram analisados 410 doentes (68\% adultos), com uma idade mediana (percentil 25-percentil 75) de 28 (16-46) anos. Foram identificados três clusters [média CARAT-T(min-max)]: cluster I [27(24-30)], cluster 2 [19(14-23)] e cluster 3 [10(2-13)]. Os doentes no cluster I (34\%) apresentavam melhor controlo da asma, melhor qualidade de vida, maior adesão aos inaladores e usavam um único inalador. Os doentes nos clusters 2 (50\%) e 3 (16\%) tinham a asma não controlada, menor adesão aos inaladores, mais sintomas de ansiedade e depressão e mais de metade reportavam pelo menos uma exacerbação no último ano. Adicionalmente, os doentes no cluster 3 eram predominantemente mulheres, tinham mais consultas médicas não agendadas, apresentavam mais sintomas de ansiedade, percebiam uma maior necessidade dos inaladores, mas também uma maior preocupação associada ao seu uso. Não se verificaram diferenças na idade, índice de massa corporal, função pulmonar, hábitos tabágicos, hospitalizações ou tempo de seguimento pelo médico especialista. Conclusões: Um método não supervisionado baseado no CARAT-T, identificou 3 clusters de doentes com diferentes características clínicas. $O$ cluster com melhor controlo apresenta um ponto de corte semelhante ao estabelecido no estudo de validação do CARAT. Este estudo sugere ainda a existência de um ponto de corte adicional para distinguir doença mais grave. Mais investigação é necessária para validar os clusters identificados.

Palavras-chave: Análise de clusters, asma, classificação, controlo da asma, teste de controlo da asma e rinite alérgica.

\section{INTRODUCTION}

A sthma is a common, chronic disease characterised by airway inflammation'. The long-term goals of asthma management are to achieve good control of symptoms and minimise future risk of exacerbations'. However, large observational studies have shown that these goals are not being easily achieved, even in patients with mild disease ${ }^{2-4}$.

Treatments can be very successful for some patients but not for others, leading to poor outcomes, unnecessary suffering and elevated direct and indirect costs ${ }^{5,6}$. This is mainly related to the heterogeneous nature of asthma', supporting the existence of distinct asthma control profiles, which differ in their characteristics and treatment responsiveness.
Unsupervised methods, particularly cluster analysis, have been used to identify subtypes of asthma with similar characteristics to predict future risks and/or to contribute for the implementation of personalised therapies $^{7,8}$. However, most of the studies that identified asthma clusters were based on clinical and inflammatory biomarkers ${ }^{9-12}$ of adult patients with moderate to severe asthma, preventing clusters' generalization to younger and/or less severe patients and their implementation into real practice. Further studies that explore subtypes of asthma control using data easily obtained in clinical practice, such as questionnaire-based information, could unravel the complex links underlying asthma control.

The Control of Allergic Rhinitis and Asthma Test (CARAT) is a self-administered questionnaire commonly used to assess asthma control both in clinical 
studies and clinical practice ${ }^{13}$. It is composed of 10 questions that address upper and lower airway symptoms, sleep interference, activities limitation, and the need to increase medication over a 4-week period. The total score (CARAT-T) is calculated by summing the score of each question, resulting in a range of $0-30$ points. In the original validation study, a CARAT-T>24 was indicative of good disease control. This work also showed that CARAT-T can be used to compare groups and to evaluate individual patients over time. However, to date, the CARAT-T ability to identify asthma control clusters was not explored.

This preliminary study aimed to identify asthma control clusters based on CARAT-T in a cohort of Portuguese adolescents and adults with persistent asthma and to compare patients' characteristics among the obtained clusters.

\section{MATERIAL AND METHODS}

\section{Study design}

Two prospective observational studies of the INSPIRERS project were analysed ${ }^{14,15}$ and data from initial face-to-face visit and I-week telephone interview were collected. A convenience sample of patients with persistent asthma was recruited between November 2017 and June 2018 at 29 allergy, pulmonology and paediatric secondary care outpatient clinics covering 6 Portugal regions (North, Center, Lisbon, Algarve, Azores, Madeira). The study protocols were approved by the ethics committees of all participating centres and by the national data protection committee. The study was conducted in accordance with the ethical standards established in the Declaration of Helsinki of 1946. Eligible patients were approached by physicians during medical visits and written informed consent was obtained before enrolment in the study. Adult patients signed a consent form; adolescents signed an assent form and a parental consent form was also obtained. The study is reported according to STROBE
(Strengthening the Reporting of Observational Studies in Epidemiology) guidelines ${ }^{16}$.

\section{Participants}

Patients were included if they had a previous medical diagnosis of persistent asthma; were at least 13 years old (13-17 years adolescents; $\geq 18$ years adults); and had an active prescription for an inhaled controller medication for asthma. All inhaled controller treatments were allowed and there was no change in any prescribed medication in relation to the participation in these studies. Patients were excluded if they had a diagnosis of a chronic lung disease other than asthma or a diagnosis of another significant chronic condition with possible interference with the study aims.

\section{Data collection}

During the initial face-to-face visit, data were collected from both physicians and patients. Physicians answered a questionnaire including: assessment of patients' asthma control according to the Global Initiative for Asthma (GINA)'; last known value of percent predicted Forced Expiratory Volume in first second $\left(\mathrm{FEV}_{1}\right)$; number of exacerbations, defined as episodes of progressive increase in shortness of breath, cough, wheezing, and/or chest tightness, requiring change in maintenance therapy ${ }^{17}$; use of health care resources, namely number of unscheduled medical visits and number of hospital admissions; and specialist follow-up time (measured in months). Physicians also reported the patients' current asthma treatment, including inhaled medication, allergen immunotherapy and biologic therapy.

Demographic - age, gender, smoking habits - and anthropometric - height, weight - data were collected from patients, along with health information as described next. Asthma control in the patients' perspective was assessed with CARAT'13. The total score (CARAT-T) is calculated by summing the score of each of the 10 questions, resulting in a range of $0-30$ points. A score $>24$ indicates good disease control. 
The Portuguese version of the Hospital Anxiety and Depression Scale (HADS) was used to assess anxiety and depression symptoms ${ }^{18}$. The HADS contains 14 items, seven measuring anxiety symptoms (HADS-A) and seven depression symptoms (HADS-D), which are scored separately. Each item has a 4-point response category, so the possible scores range from 0 (minimum symptom load) to 21 (maximum symptom load) for HADS-A and for HADS-D. A score $\geq 8$ in the HADS-A/HADS-D was used to consider the presence of clinically significant anxiety and depression symptoms ${ }^{18}$.

EQ-5D visual analogue scale (VAS) was used to assess health-related quality of life ${ }^{19,20}$. The VAS ranges from 0 (worst imaginable health state) to 100 (best imaginable health state) millimetres. Patients assessed their global adherence to inhaled controller medication for asthma during the previous week also using a VAS, ranging from 0 (worst) to 100 (best) millimetres ${ }^{21}$.

Approximately one week later ${ }^{14}$, through a telephone interview, patients were asked about their attitudes and beliefs in relation to their inhalers using the Portuguese version of the specific Beliefs about Medicines Questionnaire (BMQ-Specific) ${ }^{22}$. The BMQ-Specific is an II-item questionnaire that comprises two subscales: a 5 -item Necessity scale, to assess beliefs about the necessity for prescribed medication (Specific-Necessity), and a 6-item Concerns scale, to assess beliefs about the danger of dependence and long-term toxicity and the disruptive effects of medication (Specific-Concerns). Each item is scored on a 5 -point Likert scale (from I = strongly disagree to $5=$ strongly agree), and the total scores for the Necessity and Concerns subscales range from 5 to 25 and from 6 to 30, respectively. The higher the score, the greater is the patient's belief in the concept represented by the scale 22 .

\section{Statistical Analysis}

Descriptive statistics were used to characterise the sample. Normality of each variable was investigated with Kolmogorov-Smirnov Tests and visual analysis of histograms. To identify asthma control profiles based on CARAT-T, we conducted hierarchical cluster analysis using a squared Euclidean distance measure to assess similarity/dissimilarity across variables, and between-groups linkage method for combining clusters. The Bayesian Information Criterion (BIC) was also calculated for the number of clusters obtained. To compare differences among clusters for continuous variables, one-way ANOVA (normally distributed) or Kruskal-Wallis test (not normally distributed) with Bonferroni correction were used. Chi-square tests were used for categorical variables. Statistical analyses were performed using IBM SPSS Statistics version 25.0 (IBM Corporation, Armonk, NY, USA) and plots were created using GraphPad Prism version 6.0 (GraphPad Software, Inc., La Jolla, CA, USA). The level of significance was set at 0.05 .

\section{RESULTS}

\section{Participants}

From the 413 patients included in both studies, 410 had complete data on CARAT. Patients were mostly adults $(68 \%)$ and female (61\%). Characteristics of the participants are shown in Table I.

\section{Clusters of asthma control}

Three clusters were identified as shown in Figure I $(B I C=97.5)$. Cluster 2 was the largest cluster including half of the participants $(n=204,50 \%)$, followed by cluster I $(n=|4|, 34 \%)$ and cluster $3(n=65,16 \%)$.

Characteristics of each cluster are presented on Table 2. Most patients in cluster I had their asthma controlled both using the CARAT cut-off or GINA classification. They were also characterized by higher inhaler adherence, use of a single inhaler ( $45 \%$ in a once-daily regimen), better quality of life and equal gender distribution.

All patients in clusters 2 and 3 had uncontrolled asthma using the CARAT cut-off and more than half had 
Cristina Jácome, Rita Amaral, Rute Almeida, Ana Margarida Pereira, et al.

Table I. Participants' characteristics $(n=410)$.

\begin{tabular}{|l|c|c|}
\hline & \multicolumn{2}{|c|}{ Total (n=410) } \\
\hline Age, median (P25-P75), years & 28 & $(16-46)$ \\
\hline Adults & 280 & $(68 \%)$ \\
\hline Female & 249 & $(61 \%)$ \\
\hline BMI, median (P25-P75), kg/m² & 23.7 & $(21.2-27.4)$ \\
\hline Smoking status & & \\
Never smoker & 314 & $(77 \%)$ \\
Ex-smoker & 67 & $(16 \%)$ \\
Current smoker & 29 & $(7 \%)$ \\
\hline Inhaled medication & & \\
ICS/LABA & 340 & $(83 \%)$ \\
ICS & 68 & $(16 \%)$ \\
LAMA & 54 & $(13 \%)$ \\
LABA & 11 & $(3 \%)$ \\
LABA/LAMA & 3 & $(1 \%)$ \\
SABA & 79 & $(19 \%)$ \\
SAMA & 3 & $(1 \%)$ \\
\hline Allergen immunotherapy & 74 & $(18 \%)$ \\
\hline Biologic therapy & 25 & $(6 \%)$ \\
\hline CARAT-T, mean (SD) & 20.2 & $(6.3)$ \\
\hline
\end{tabular}

Values are shown as $\mathrm{n}(\%)$ unless otherwise indicated. $\mathrm{BMI}$ - body mass index; CARAT-T - Control of Allergic Rhinitis and Asthma Test total score; ICS - inhaled corticosteroids; LABA - long-acting beta-agonists; LAMA - long-acting muscarinic receptor antagonists; P25-P75 - percentile 25 to percentile 75; SABA - short-acting beta-agonists; SAMA short-acting muscarinic-antagonists. partly controlled/uncontrolled asthma using GINA classification. Patients in clusters 2 and 3 had also lower inhaler adherence, more than half had at least one exacerbation in the previous year and more symptoms of anxiety and depression.

Furthermore, patients in cluster 3 were predominantly female, had more unscheduled medical visits, presented more symptoms of anxiety, perceived a higher necessity of their prescribed inhalers but also higher levels of concern about taking these inhalers.

There were no significant differences in age, $\mathrm{BMI}, \mathrm{FEV}_{\mathrm{l}}$, smoking status, hospital admissions or specialist follow-up time among clusters.

\section{DISCUSSION}

To our knowledge, this is the first study using an unsupervised method to identify subgroups of asthma control solely based on the total score of the self-reported questionnaire CARAT. We were able to identify 3 clusters of patients that differed in a number of characteristics such as adherence to inhaled medication, beliefs about inhaled medication, number of inhalers prescribed, num-

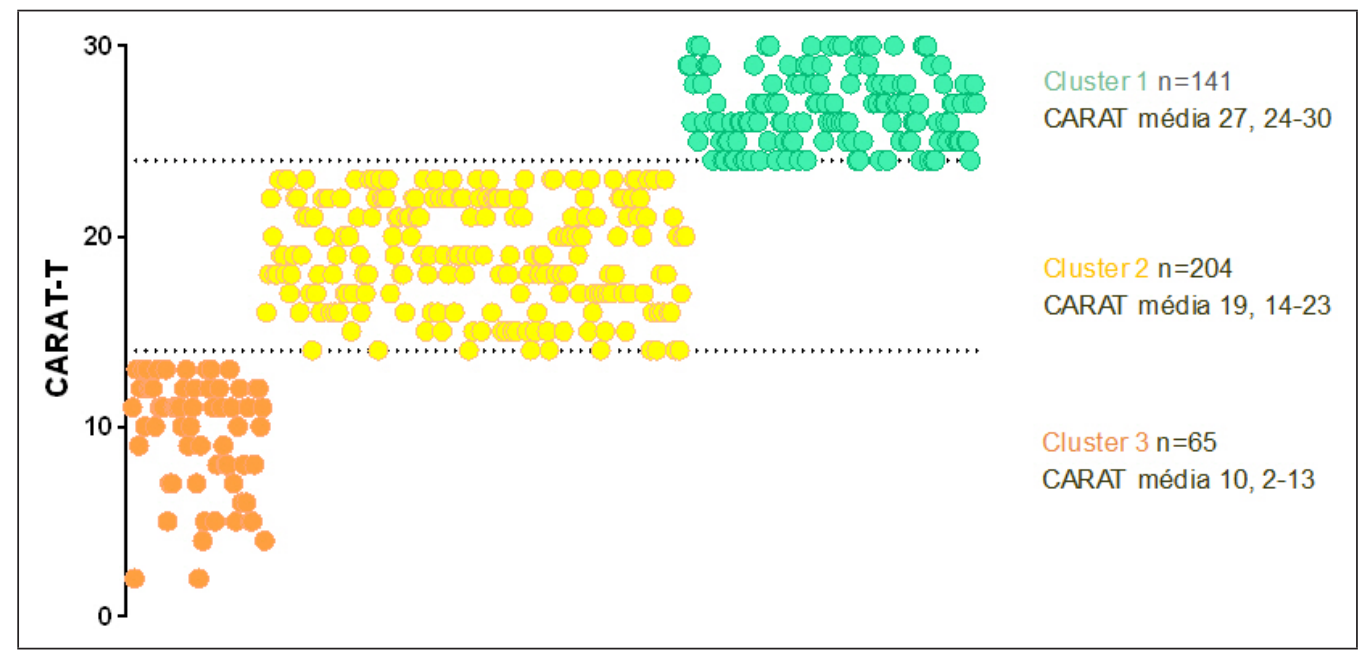

Figure I. Clusters based on Control of Allergic Rhinitis and Asthma Test (CARAT) total score (CARAT mean, range) 
Table 2. Participants' characteristics across the 3 clusters $(n=410)$.

\begin{tabular}{|c|c|c|c|c|c|c|c|c|c|c|}
\hline \multirow[b]{2}{*}{ Age, median (P25-P75) years } & \multicolumn{2}{|c|}{$\begin{array}{c}\text { Cluster I (CI) } \\
n=|4|\end{array}$} & \multicolumn{2}{|c|}{$\begin{array}{c}\text { Cluster } 2(\mathrm{C} 2) \\
\mathrm{n}=204\end{array}$} & \multicolumn{2}{|c|}{$\underset{n=65}{\text { Cluster } 3(\mathrm{C} 3)}$} & \multirow{2}{*}{\begin{tabular}{|c|}
$p$-value \\
$0.25 \mid$ \\
\end{tabular}} & \multirow{2}{*}{\begin{tabular}{|c|}
$\mathbf{C l}$ vs $\mathrm{C2}$ \\
$\mathrm{p}$-value
\end{tabular}} & \multirow[t]{2}{*}{$\begin{array}{c}\mathrm{Cl} \text { vs C3 } \\
\mathrm{p} \text {-value }\end{array}$} & \multirow[t]{2}{*}{$\begin{array}{c}\text { C2 vs C3 } \\
\text { p-value }\end{array}$} \\
\hline & 29 & {$[16-45]$} & 26 & {$[16-46]$} & 34.5 & {$[16.3-52.5]$} & & & & \\
\hline Female & 71 & (50.4) & 128 & (62.7) & 50 & (76.9) & 0.001 & 0.022 & $<0.001$ & 0.035 \\
\hline BMI, median (P25-P75) kg/m² & 23.7 & [20.8-27] & 23.7 & [21.4-27.3] & 23.6 & {$[20.9,28.7]$} & 0.673 & & & \\
\hline $\mathrm{FEV}$, \% predicted, mean (SD) & 93.2 & $(16.5)$ & 92.6 & $(19.4)$ & 89.2 & $(19.8)$ & 0.411 & & & \\
\hline $\begin{array}{l}\text { Smoking status } \\
\text { Never smoker } \\
\text { Ex-smoker } \\
\text { Current smoker }\end{array}$ & $\begin{array}{c}109 \\
23 \\
9\end{array}$ & $\begin{array}{c}(77.3) \\
(16.3) \\
(6.4)\end{array}$ & $\begin{array}{l}155 \\
30 \\
17\end{array}$ & $\begin{array}{l}(76) \\
(14.7) \\
(8.3)\end{array}$ & $\begin{array}{c}48 \\
14 \\
3\end{array}$ & $\begin{array}{c}(73.8) \\
(21.5) \\
(4.6)\end{array}$ & $\begin{array}{l}0.608 \\
0.440 \\
0.543\end{array}$ & & & \\
\hline Inhaler Adherence VAS, median (P25-P75) & 90 & {$[76.8,98]$} & 80 & {$[65,95]$} & 80 & {$[54,95]$} & 0.005 & 0.005 & 0.007 & 0.506 \\
\hline Single inhaler & 106 & $(75.2)$ & 122 & (59.8) & 45 & $(69.2)$ & 0.033 & 0.009 & 0.354 & 0.318 \\
\hline Necessity, median (P25-P75) & 19 & {$[17,21]$} & 19 & {$[16,22]$} & 21 & {$[18,23]$} & 0.008 & 0.524 & 0.007 & 0.020 \\
\hline Concerns, median (P25-P75) & 15 & {$[12,17]$} & 16 & {$[12.8,19]$} & 17 & {$[14,21]$} & 0.006 & 0.474 & 0.004 & 0.068 \\
\hline Controlled CARAT & 119 & $(84.4)$ & 0 & & 0 & & $<0.001$ & $<0.001$ & $<0.001$ & - \\
\hline $\begin{array}{l}\text { GINA assessment symptom control } \\
\text { Well-controlled } \\
\text { Partly controlled/ Uncontrolled }\end{array}$ & $\begin{array}{l}112 \\
29 \\
\end{array}$ & $\begin{array}{l}(79.4) \\
(20.6)\end{array}$ & $\begin{array}{l}89 \\
113 \\
\end{array}$ & $\begin{array}{l}(43.6) \\
(55.4)\end{array}$ & $\begin{array}{l}17 \\
46\end{array}$ & $\begin{array}{l}(26.2) \\
(70.8)\end{array}$ & $<0.001$ & $<0.001$ & $<0.001$ & 0.016 \\
\hline$\geq I$ exacerbations past year & 51 & $(36.2)$ & 107 & $(52.5)$ & 41 & $(63.1)$ & $<0.001$ & 0.001 & $<0.001$ & 0.101 \\
\hline $\begin{array}{l}\text { Number unscheduled medical visits past year, } \\
\text { median (P25-P75) }\end{array}$ & 0 & {$[0,1]$} & 1 & {$[1,2]$} & I & {$[0.5,2.5]$} & 0.020 & 0.329 & 0.015 & 0.253 \\
\hline$\geq I$ hospital admissions past year & 3 & (2.1) & 7 & $(3.4)$ & 5 & $(7.7)$ & 0.431 & & & \\
\hline Anxiety symptoms & 32 & $(22.7)$ & 67 & $(32.8)$ & 36 & $(55.4)$ & $<0.001$ & 0.053 & $<0.001$ & 0.002 \\
\hline Depression symptoms & 7 & $(5)$ & 27 & $(13.2)$ & 16 & $(24.6)$ & $<0.001$ & 0.016 & $<0.001$ & 0.034 \\
\hline EQ-5DVAS, median (P25-P75) & 88.5 & {$[80,91.1]$} & 80 & {$[70,90]$} & 70 & {$[55,80]$} & $<0.001$ & $<0.001$ & $<0.001$ & $<0.001$ \\
\hline Specialist follow up time $\geq 1$ year & 113 & $(80.1)$ & 144 & $(70.6)$ & 49 & $(75.4)$ & 0.169 & & & \\
\hline
\end{tabular}

Values are shown as $\mathrm{n}(\%)$ unless otherwise indicated. Significant values marked in bold.

BMI - body mass index; CARAT -Control of Allergic Rhinitis and Asthma Test; FEVI - forced expiratory volume in one second; GINA - Global Initiative for Asthma; P25-P75 - percentile 25 to percentile 75; VAS - visual analogue scale.

ber of exacerbations and unscheduled medical visits in the previous year, symptoms of anxiety and depression, health-related quality of life and gender distribution. The clusters found were not determined by any a priori clinical knowledge, but rather on the total score of an asthma control self-reported questionnaire, easily applied in daily clinical practice.

From the distributions of CARAT-T across the 3 clusters, it is possible to observe that two cut-offs ( $\geq 24$ and $\geq 14$ ) emerged from the unsupervised analyses. The cut-off for controlled disease is in line with the cut-off suggested in the original validation study of CARAT $(>24)^{23}$. The slight difference might be related with differences in the samples used. The validation study included a smaller sample of adults with asthma $(n=62)$ recruited from 4 allergy secondary care outpatient clinics in three Portuguese regions ${ }^{23}$; while in the present study a larger and more representative sample was used: adolescents were also included and patients were recruited by 3 medical specialities (allergy, pulmonology and paediatrics) from 6 
Portuguese regions. An additional CARAT cut-off of 14 is for the first time proposed and seems to be able to distinguish patients with partly controlled disease and uncontrolled disease. This cut-off may be useful to clinicians to identify individuals with different risk levels and to individualize care in order to maximise outcomes. Nevertheless, this cut-off needs further validation before implementation into clinical practice.

Patients in the cluster with better asthma control had higher self-reported adherence to inhaled medication compared to patients from the other two clusters. Although it is possible that all patients were overestimating real adherence ${ }^{24,25}$, this result suggests that asthma control is associated with adherence behaviours. In addition, most patients in this cluster had a single inhaler, and almost half in a once-daily regimen; possibly suggesting that simple therapeutic plans are related with better adherence and asthma control ${ }^{26}$. A randomized control study with patients with asthma has previously shown that using a single inhaler for both maintenance treatment and symptom relief increased the dose of inhaled corticosteroid taken ${ }^{27}$. But evidence on the link between adherence and number of drugs or daily doses is still inconclusive ${ }^{28}$. This may be related to the fact that there is no "gold standard" in evaluating adherence ${ }^{29}$. Patients in the cluster with worst asthma control perceived a higher necessity of their prescribed inhalers, but also higher levels of concern about taking these inhalers. Indeed, more concerns about medication have been related to worse adherence ${ }^{28}$.

Patients from clusters 2 and 3 , as expected, had more exacerbations than patients from cluster $\mathrm{I}$, as result of poor disease control. These patients had also poorer quality of life and more frequently depression. These characteristics have been previously found to distinguish asthma subtypes ${ }^{7,10,11}$. Patients in cluster 3 were in addition predominantly female, had more unscheduled medical visits, presented more symptoms of anxiety. These characteristics are commonly present in patients with difficult to treat asthma or severe asthma ${ }^{30}$. In fact, this cluster includes $16 \%$ of the patients, which is in line with described prevalence of difficult-to-treat asthma $(17 \%)^{31}$ and severe asthma $(3-10 \%)^{31,32}$.

Strengths and limitations of this study should be recognized. The inclusion of adolescents with persistent asthma in our sample and the recruitment at 29 secondary healthcare centres are strengths of the present study. Yet patients were recruited by convenience sampling, which limits the generalizability of the results. Population studies with larger sample size and an extended age range (including children and older adults) and from other healthcare settings (e.g. primary care) should be conducted in future. Another strength of our study was the use of variables easily obtained in clinical practice. Patients' allergic profile, treatment step and comorbidities (e.g., rhinitis) were not analysed but might also play a role in cluster differentiation. Future studies could address these issues in order to validate the three asthma control clusters identified or identify other types. These asthma control clusters were identified using a single clustering method - hierarchical cluster analysis and a single variable - CARAT-T. Although this is one of the most common clustering methods used in asthma ${ }^{8,10}$, future studies using CARAT-T and/or other self-reported variables could also use other unsupervised methods that shown to be promising in identifying clusters of subjects with allergic respiratory diseases, such as latent class or profile analysis ${ }^{33,34}$.

\section{CONCLUSIONS}

Using an unsupervised method based on CARAT-T, we identified 3 clusters of patients with distinct, clinically meaningful characteristics. The cluster with better asthma control generated by this unsupervised method had a cut-value similar to the established in the validation study of CARAT. An additional cut-off, that seems to distinguish more severe disease also emerged from this preliminary analysis. Further research is necessary to better characterize the identified clusters of asthma control. 


\section{Acknowledgments}

We thank the participants and centres involved in the project Inspirers.

\section{Funding}

This work was funded by ERDF (European Regional Development Fund) through the operations: $\mathrm{POCl}-$ -0I-0I45-FEDER-029130 ("mINSPIRERS-mHealth to measure and improve adherence to medication in chronic obstructive respiratory diseases - generalisation and evaluation of gamification, peer support and advanced image processing technologies") co-funded by the COMPETE2020 (Programa Operacional Competitividade e Internacionalização), Portugal 2020 and by Portuguese Funds through FCT (Fundação para a Ciência e a Tecnologia).

\section{Conflicts of interest}

None declared.

\section{Contact:}

João Almeida Fonseca, MD, PhD

Center for Health Technology and Services Research (CINTESIS) Faculty of Medicine, Universidade do Porto

Rua Dr. Plácido da Costa, Porto 4200-450, Portugal

E-mail: fonseca.ja@gmail.com

\section{REFERENCES}

I. Global Initiative for Asthma. Global Strategy for Asthma Management and Prevention, 2019. Available from: www.ginasthma.org.

2. Postma DS, Brightling C, Baldi S, Van den Berge M, Fabbri LM, Gagnatelli $A$, et al. Exploring the relevance and extent of small airways dysfunction in asthma (ATLANTIS): baseline data from a prospective cohort study. The Lancet Respir Med 2019;7(5):402$-16$.

3. Backman H, Jansson S-A, Stridsman C, Muellerova H, Wurst K, Hedman L, et al. Chronic airway obstruction in a population-based adult asthma cohort: Prevalence, incidence and prognostic factors. Respir Med 2018;138:115-22.

4. Price D, Fletcher M, van der Molen T. Asthma control and management in 8,000 European patients: the REcognise Asthma and LInk to Symptoms and Experience (REALISE) survey. NPJ Prim Care Respir Med 2014;24:14009.
5. Demoly P, Annunziata K, Gubba E, Adamek L. Repeated cross-sectional survey of patient-reported asthma control in Europe in the past 5 years. Eur Respir Rev 2012;2I(I23):66-74.

6. Barbosa JP, Ferreira-Magalhaes M, Sa-Sousa A, Azevedo LF, Fonseca JA. Cost of asthma in Portuguese adults: A population-based, cost-of-illness study. Rev Port Pneumol (2006) 2017;23(6):323-30.

7. Baptist AP, Hao W, Karamched KR, Kaur B, Carpenter L, Song PXK. Distinct Asthma Phenotypes Among Older Adults with Asthma. J Allergy Clin Immunol Pract 2018;6(I):244-9.e2.

8. Delgado-Eckert E, Fuchs O, Kumar N, Pekkanen J, Dalphin JC, Riedler J, et al. Functional phenotypes determined by fluctuation-based clustering of lung function measurements in healthy and asthmatic cohort participants. Thorax 2018;73(2):107-15.

9. Lefaudeux D, De Meulder B, Loza MJ, Peffer N, Rowe A, Baribaud $F$, et al. U-BIOPRED clinical adult asthma clusters linked to a subset of sputum omics. J Allergy Clin Immunol 20I7;139(6):1797-807.

10. Moore WC, Meyers DA, Wenzel SE, Teague WG, Li H, Li X, et al. Identification of asthma phenotypes using cluster analysis in the Severe Asthma Research Program. Am J Respir Crit Care Med 2010;18I(4):315-23.

II. Wu W, Bleecker E, Moore W, Busse WW, Castro M, Chung KF, et al. Unsupervised phenotyping of Severe Asthma Research Program participants using expanded lung data. J Allergy Clin Immunol 2014;133(5): 1280-8.

12. van der Molen T, Fletcher M, Price D. Identifying Patient Attitudinal Clusters Associated with Asthma Control: The European REALISE Survey. J Allergy Clin Immunol Pract 2018;6(3):962-7I.

13. Fonseca JA, Nogueira-Silva L, Morais-Almeida M, Azevedo L, Sa-Sousa A, Branco-Ferreira $M$, et al. Validation of a questionnaire (CARATI0) to assess rhinitis and asthma in patients with asthma. Allergy 2010;65(8):1042-8.

14. Jácome C, Guedes R, Almeida R, Teixeira JF, Pinho B, Vieira- Marques P, et al. mINSPIRERS - Estudo da exequibilidade de uma aplicação móvel para medição e melhoria da adesão à medicação inalada de controlo em adolescentes e adultos com asma persistente. Protocolo de um estudo observacional multicêntrico. Rev Port Imunoalergologia 2018;26:47-6I.

15. Jacome C, Pereira AM, Almeida R, Ferreira-Magalhaes M, Couto $M$, Araujo $L$, et al. Patient-physician discordance in assessment of adherence to inhaled controller medication: a cross-sectional analysis of two cohorts. BMJ Open 2019;9(II):e031732.

16. Vandenbroucke JP, von Elm E, Altman DG, Gotzsche PC, Mulrow $C D$, Pocock SJ, et al. Strengthening the Reporting of Observational Studies in Epidemiology (STROBE): explanation and elaboration. Int J Surg 2014;I2(12):1500-24.

17. Loymans RJ, Ter Riet G, Sterk PJ. Definitions of asthma exacerbations. Curr Opin Allergy Clin Immunol 20II;II(3):I8I-6.

18. Pais-Ribeiro J, Silva I, Ferreira T, Martins A, Meneses R, Baltar M. Validation study of a Portuguese version of the Hospital Anx- 
iety and Depression Scale. Psychol Health Med 2007;12(2):225-35; quiz 35-7.

19. Hung MC, Lu WS, Chen SS, Hou WH, Hsieh CL, Wang JD. Validation of the EQ-5D in Patients with Traumatic Limb Injury. J Occup Rehabil 2015;25(2):387-93.

20. McPhail S, Lane P, Russell T, Brauer SG, Urry S, Jasiewicz J, et al. Telephone reliability of the Frenchay Activity Index and EQ-5D amongst older adults. Health Qual Life Outcomes 2009;7(I):48.

21. Jonsdottir H, Opjordsmoen S, Birkenaes AB, Engh JA, Ringen PA, Vaskinn $A$, et al. Medication adherence in outpatients with severe mental disorders: relation between self-reports and serum level. J Clin Psychopharmacol 2010;30(2):169-75.

22. Salgado T, Marques A, Geraldes L, Benrimoj S, Horne R, Fernandez-Llimos F. Cross-cultural adaptation of The Beliefs about Medicines Questionnaire into Portuguese. Sao Paulo medical journal = Revista paulista de medicina 20I3;13I(2):88-94.

23. Fonseca JA, Nogueira-Silva L, Morais-Almeida M, Sa-Sousa A, Azevedo LF, Ferreira J, et al. Control of Allergic Rhinitis and Asthma Test (CARAT) can be used to assess individual patients over time. Clin Transl Allergy 2012;2(I):16.

24. Nau DP, Steinke DT, Williams LK, Austin R, Lafata JE, Divine G, et al. Adherence analysis using visual analog scale versus claims-based estimation. Ann Pharmacother 2007;4I(II):1792-7.

25. Kalichman SC, Amaral CM, Swetzes C, Jones M, Macy R, Kalichman $M O$, et al. A simple single-item rating scale to measure medication adherence: further evidence for convergent validity. J Int Assoc Physicians AIDS Care (Chic) 2009;8(6):367-74.

26. Hassan M, Davies SE, Trethewey SP, Mansur AH. Prevalence and predictors of adherence to controller therapy in adult patients with severe/difficult-to-treat asthma: a systematic review and meta-analysis. J Asthma 2019;in press:I-I0.

27. Sovani MP, Whale Cl, Oborne J, Cooper S, Mortimer K, Ekstrom $\mathrm{T}$, et al. Poor adherence with inhaled corticosteroids for asthma: can using a single inhaler containing budesonide and formoterol help? Br J Gen Pract 2008;58(546):37-43.

28. Dima AL, Hernandez G, Cunillera O, Ferrer M, de Bruin M. Asthma inhaler adherence determinants in adults: systematic review of observational data. Eur Respir J 2015;45(4):994-1018.

29. Anghel LA, Farcas AM, Oprean RN. An overview of the common methods used to measure treatment adherence. Med Pharm Rep 2019;92(2):117-22.

30. Global Initiative for Asthma. Difficult-to-treat \& Severe Asthma in adolescents and adult patients: Diagnosis and Management, 2019. Available from: www.ginasthma.org.

31. Hekking P-PW, Wener RR, Amelink M, Zwinderman AH, Bouvy $\mathrm{ML}, \mathrm{Bel} \mathrm{EH}$. The prevalence of severe refractory asthma. J Allergy Clin Immunol 2015;135(4):896-902.

32. Chung KF, Wenzel SE, Brozek JL, Bush A, Castro M, Sterk PJ, et al. International ERS/ATS guidelines on definition, evaluation and treatment of severe asthma. Eur Respir J 2014;43(2):343.

33. Amaral R, Bousquet J, Pereira AM, Araújo LM, Sá-Sousa A, Jacinto $\mathrm{T}$, et al. Disentangling the heterogeneity of allergic respiratory diseases by latent class analysis reveals novel phenotypes. Allergy 2019;74(4):698-708.

34. Siroux V, Basagaña X, Boudier A, Pin I, Garcia-Aymerich J, Vesin $A$, et al. Identifying adult asthma phenotypes using a clustering approach. Eur Respir J 2011;38(2):310. 